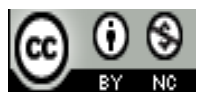

Jurnal Pendidikan IPS Indonesia is licensed under

A Creative Commons Attribution-Non Commercial 4.0 International License

\title{
CASE STUDY ON VIOLENCE AGAINST AHMADIYYA ADHERENTS IN INDONESIA IN THE REIGN OF PRESIDENT SUSILO BAMBANG YUDHOYONO
}

\author{
Agung Yudhistira Nugroho, $\mathrm{MA}^{1)}$ \\ 1) UNTAG, Jakarta, Indonesia \\ E-mail:aijn_agung@yahoo.com
}

\begin{abstract}
Ahmadiyya saga in Indonesia just like a never ending stories. Starting from the non-acceptance of them in society, violence and intimidation, pressure from Islamic organizations and the Indonesian Ulema Council. The government placed in the position of a dilemma. On one hand the government is required to protect its citizens in this regard Ahmadiyya followers are intimidated by a group or community that does not accept them, on the other hand the government must determine the manner in which the Government should disband and ban the Ahmadiyya. When the Ahmadiyya and other religious people defended using the excuse of the Universal Declaration of Human Rights, the UN Human Rights artificial precisely considered weak and unable to protect Palestinians from Israeli attacks. From here then comes the problem of where the followers of the Ahmadiyya to be able to put themselves in a society that does not accept them, Not an easy task to find the right solution for this case. Solutions that can be offered is to address these differences by looking at the cornerstone of our country Pancasila which has a single slogan Unity in Diversity. In that case author also concern about how the the government in maintaining security for Ahmadiyya followers whom a citizen of Indonesia as well? This is what will be studied in this paper.
\end{abstract}

Keywords: Ahmadiyya, Human Security, Islamic Organizations, The Government of Indonesia, Radicalism.

\section{INTRODUCTION}

Indonesia Violence committed against Ahmadiyya in Indonesia has increased in recent years. In Lombok, West Nusa Tenggara, the Ahmadiyya community were expelled from their land and had to stay in Mataram Transito building used as a place of refuge for more than 7 years. In some cities like Tangerang, Bogor and Tasikmalaya, the Ahmadiyya congregation many death threats if they are still running a worship.

Ahmadiyya is a sect of Islam, founded by Mirza Ghulam Ahmad in 1889 in India. The fundamental difference Ahmadiyya teachings with the teachings of Islam whom are admitted Mirza Ghulam Ahmad as the Mahdi. It is completely contrary to the fundamental Islamic beliefs that do not recognize Ghulam Ahmad as the Imam Mahdi, because of the religious beliefs of Islam considers Muhammad was the last prophet. Coupled with the presumption Ahmadiyya has its own holy book that is different from the Koran. Although Ahmadiyya themselves against the assumption. They declared the
Ahmadiyya holy book the Koran remains, but based on the interpretation of Mirza Ghulam Ahmad.

Ahmadiyya itself went to Indonesia and named themselves as Jamaah Islam Indonesia, and approved as a legal entity by the Minister of Justice in 1953.Since recognized as a legal entity, for more than fifty years of Ahmadiyya coexist in peace and security with the Moslems and other religions in Indonesia. Receipt of Ahmadiyya in Indonesia at that time can be seen from WR. Supratman confirmed as a national hero. Even Ahmadiyya mosques built in many places and its adherents are free to run his worship.

After the reform and especially during the reign of Susilo Bambang Yudhoyono, everything changed. In the administration of President Yudhoyono, the Indonesian Ulema Council (MUI) have a dominant influence in the running of Islamic law. So that in 2005, the MUI issued a fatwa on the Ahmadiyya and asked Yudhoyono to ban all related to Ahmadiyya . From the fatwa is what later became the basis for the intimidation against the Ahmadiyya. 
On the other hand the existence of a coalition of Islamic organizations initiated by Hizb ut-Tahrir Indonesia (HTI) with the Muslim Forum, the Islamic Defenders Front and the Indonesian Mujahidin Council, which then lobbies the Coordinating Board for Monitoring Mystical Beliefs in Society (Bakor Pakem), to ban Ahmadiyya . Bakor Pakem itself as a forum of various government agencies under the supervision of the Attorney General. The purpose of the Hizb, which is the parent of HTI is headquartered in London, is establishing Islamic caliphate, a kind of Ottoman Empire, with members of all Islamic countries around the world.

Based on MUI fatwa's and supported by other Islamic groups, acts of violence against the Ahmadiyya in various places in Indonesia are common, took so many casualties. The peak of this riots held in Cikeusik, Banten in 2011, that several of people were killed when hundreds of people tried to expel the Ahmadiyya study group.

\section{Research Question}

Is violence against Ahmadiyya due to nonfulfillment of the security community by the government of Susilo Bambang Yudhoyono?.

\section{DISCUSSIONS}

Basically, human nature is less like the difference. The differences are often regarded as incompatible with the eyes of the majority of individuals or groups. Especially when it concerns the differences more fundamental problems, namely religion. See the case on the Ahmadiyya adherents in criminalization by other Muslims, quite contrary to Pancasila. Where Indonesia is a country that is based on Pancasila is not a religion.

In creating a sense of security for all citizens and the protection of human rights is a constitutional duty of the government. Therefore, protection of Ahmadiyya from threats to the right to security in freedom in exercising their religion and a real threat to human rights are appropriately become the constitutional duty of the government. The whole basis of the law, instruments, and devices for protecting against its citizens must be provided by the government. However, in the name of constitutional duties, does not mean the country is justified devices perform actions beyond the limits defined democratic authority through legislation. Restriction of powers in dealing deal with Ahmadiyah is an absolute done by the government to protect its citizens in the running of religious freedom.

Ahmadiyya cases started when SBY as head of government had a close relationship with the Islamists community. In that result President gives an absolute authority to the MUI. This situation has never been done by SBY's predecessors. In the Soeharto's era Islamic organizations are marginalized and not given a chance to develop into force. Every movement that lead to acts of radicalism and violence immediately suppressed to prevent the disruption of national stability and economic growth in Indonesia. Soeharto holds a dominant role in every aspect of life. While the strength of the democratic system and control functions scattered in various groups and institutions. Therefore, the President must constantly strive to always get support from groups who have the power and the control. From there SBY put MUI as a controller of the control of Islam in Indonesia.

A security issue itself is usually assumed to be a problem associated between countries, in maintaining and protecting the security of a country from threats that come from other countries (Traditional Security). However, with the awareness that the security threats come not only the state, then the concept of security of a military nature was shifted so that a broader concept of security, it is then referred to as NonTraditional Security.

This is in line with the opinion of Barry Buzan, who stated that there are different types of threats that are no longer new and traditional security concerns. Here Barry Buzan assume that there are new threats that must be addressed with different studies, or the so-called Non-Traditional Security. Non-Traditional Security Studies assume that the state is not the only subject. Non-Traditional Security Studies in Copenhagen School clarify the role of objects and subjects in international security. 
Associated with the securitization process, of course, not in spite of speech act. Speech act, carried out by MUI in the form of a fatwa that forbids Ahmadiyya, encouraging other community components to criminalize Ahmadiyya. Thus the government has failed to implement the responsibility to protect $(R 2 P)$ against its citizens. Governments tend impunity violence against the Ahmadiyya . This is clearly contrary to the principle of the Pancasila state governing religious freedom in Indonesia.

It is undeniable that the securitization of religion brings its own dilemma against law enforcement officers and state officials. Individually they see their religion ideology leads them to behave is not neutral in handling cases related to religion. This is evident from the case in 2006 in Lombok. Expulsion of Ahmadiyya comes ahead of the local elections. The expulsion carried out by the religious leaders that the locals called "Tuan Guru" who is also running for the head region. When the newly elected governor, the governor, who also came from Islamic organizations are not willing to solve the problem on Ahmadiyya who have been expelled from their homeland. Plus the governor gives speech act to the Ahmadiyya to get out of the Ahmadiyya or seek asylum abroad. Here 'Local State' put option to support the banning of Ahmadiyya in Lombok be to continue to have the support of the Islamic group the majority there.

The same thing is also happening at the national level. SBY government never act to stop the criminalization of Ahmadiyya followers because they will damage relations with the Islamic group majority. As a result, the government tends to leave and turn a blind eye to criminalize the Ahmadiyya followers. The government considers the criminalization committed against Ahmadiyya is not a fundamental, because Ahmadiyya are a minority. The violence of the minority groups is the impact of the weakness of representative democracy tends to ignore the minority groups because they will not takes the influence in elections. Here the political agenda of the foundation to secure political office, with the support of Ahmadiyya will eliminate the majority support that in fact Islam is the main source of votes in the election.

\section{CONCLUSION}

For the citizens of Indonesia's national sovereignty is equal treatment of citizens regardless of their racial background, ethnicity, religion and culture. Decisions taken by the MUI is an attitude that is contrary to the state constitution and a legal order ambiguity in Indonesia. This is what will happen when state officials were united with the people to oppress minorities. Plus puts the benchmark of thought on the basis of religion of the majority, while the freedom of the right of citizens to adopt a religion or belief of each conditioned on behalf of desecration and blasphemy.

Violate the rights of Ahmadiyya to profess their belief is a denial of their rights as human beings. It is as stipulated in the UN Universal Declaration of Human Rights which has put faith and trust as the most essential rights of every human being. When the Ahmadiyya and other religious people defended using the excuse of the Universal Declaration of Human Rights, the UN Human Rights artificial precisely considered weak and unable to protect Palestinians from Israeli attacks. Islamic mass organizations in Indonesia accused the UN Declaration on Human Rights is an infidel at once artificial Islamic organizations are making themselves what they mean as a human right, namely the repression against followers of a religious sect that is not in line with them. This is compounded by the country with impunity minorities and not protecting the victims.

Government less assertive in taking a stand in placing itself as a party that has authority over the responsibility to protect. Security against minority communities increasingly marginalized. Governments tend to seek safe against his position. People power is erroneously often distorted as the absolute power to suppress the minority.

Not an easy task to find the right solution for this case. Solutions that can be offered is to address these differences by looking at the cornerstone of our country Pancasila which has a single slogan Unity in Diversity. It is undeniable 
that the political elite are too arrogant to implement the philosophy of life of the New Order that in reality there are still relevant for social life. We tend to denounce and change the order of life can still be implemented, and not impose the system is still trial and error.

Certain maturity of thought and put the interests of the nation and respect for religious freedom becomes a matter that can not be negotiable. Interests of the individual or group should be placed far below the nation's interests. Indonesia's identity during which upholds unity and appropriate based on Pancasila should be prioritized.
F. Barth, Fredrik, Kelompok-Kelompok Etnis dan Batasannya (terj), Jakarta: Published Universitas Indonesia, 1988.

B. Buzan, People, States, and Fear: An Agenda For International Security Studies In The Post-Cold War Era. London: Harvester Wheatsheaf, $2^{\text {nd }}$ edn, 1991.

B. Buzan, O.Waever, J. Wilde, Security: A New Framework of Analysis, London: Lynne Riener Publisher, 2008.

N. Iskandar, Fatwa MUI dan Gerakan Ahmadiyah Indonesia, Darul Kutubil Islamiyah, 2015.

Yusuf, Islam, Munirul, Ahmadiyah Menggugat. Jakarta: Mubarik Publishing, 2011

\section{REFERENCES}

